\title{
Seismic sources and neo-tectonics of Tehran area (North Iran)
}

\author{
Mehran Arian $^{1 *}$, Nooshin Bagha ${ }^{2}$, Rezvan Khavari ${ }^{3}$ and Hamideh Noroozpour ${ }^{4}$ \\ ${ }^{1^{*} D e p a r t m e n t}$ of Geology, Islamic Azad University, Science and Research branch, Tehran, Iran, \\ ${ }^{2}$ Department of Geology, Islamic Azad University, Science and Research branch, Tehran, Iran \\ ${ }^{3}$ Department of Geology, Islamic Azad University, Behbahan branch, Behbahan, Iran \\ ${ }^{4}$ Department of Geology, Islamic Azad University, Science and Research branch, Tehran, Iran \\ mehranarian@yahoo.com*
}

\begin{abstract}
This study records evidence of neo-tectonic activities in Tehran area. The aim of the study is to investigate the seismic sources in Tehran area and Mosha fault has introduced as the most active fault. The high seismicity potentials have appeared by integration of structural geology and active tectonics studies. Movement potential evaluation of the main faults in the current tectonic regime show that the North Tehran fault have $90 \%$ potential to movement. Also, geomorphic indexes indicate the presence of differential uplifting in the geological past. Recent activity of Tehran area is investigated by a large number of geomorphic indexes such as: drainage basin asymmetry, stream gradient. The stream network asymmetry was studied using morphometric measures of transverse topographic symmetry, asymmetry factor and drainage basin shape.
\end{abstract}

Keywords: Geomorphic, Indexes, Tectonics, Tehran, Hazard, Active.

\section{Introduction}

Tehran area is located between south borders of central Alborz in North and Central Iran plain in south. This area bounded by several active faults (Tchalenko et al., 1974). Also, it has important seismic evidence (Ambraseys \& Melville, 1982) such as 8 main seismogenic faults. One of these faults is Mosha fault which is a reverse fault with component of left lateral in younger movements with slip rate $2 \mathrm{mmy}-1$ (Solaymani et al., 2002). Further suggested slip Rate $1 \mathrm{mmy}-1$ in the more of 5 my time for Pliocene - Quaternary displacement of Mosha fault (Vernant et al., 2004).

North Tehran fault is another main fault, this fault presented as a thrust fault. In this study, we tried with total data and study on geologic evidence happened in area, for the first time consider the active tectonics of Tehran area and relatively assess to Seismic hazard of Tehran area.

This area is important from point of strategy, so, this study it is very necessary. For this aim, main seismogenic faults of area have investigated and active tectonics indexes have measured. Present-day geomorphology of Tehran area in the southern flank of Central Alborz mountain range is the result of active tectonic processes. On the basis of geomorphic indexes, we have attempted to work out the geomorphologic evolution. The recent investigations show that neo-tectonics has played a key role in the geomorphic evolution of this part of the Alborz mountain range.

Main seismogenic faults

In the studied area, after considering previous studies (Berberian et al.,1992; Ritz et al., 2006) and GIS analysis on available maps (Berberian et al., 1983; Nazari, 2005) of the area, it is understood that there exists the main Quaternary faults with high seismic sources for big
Fig. 1. Main faults map of Tehran area (top) and its epicenters of instrumental earthquakes from 1930-2011
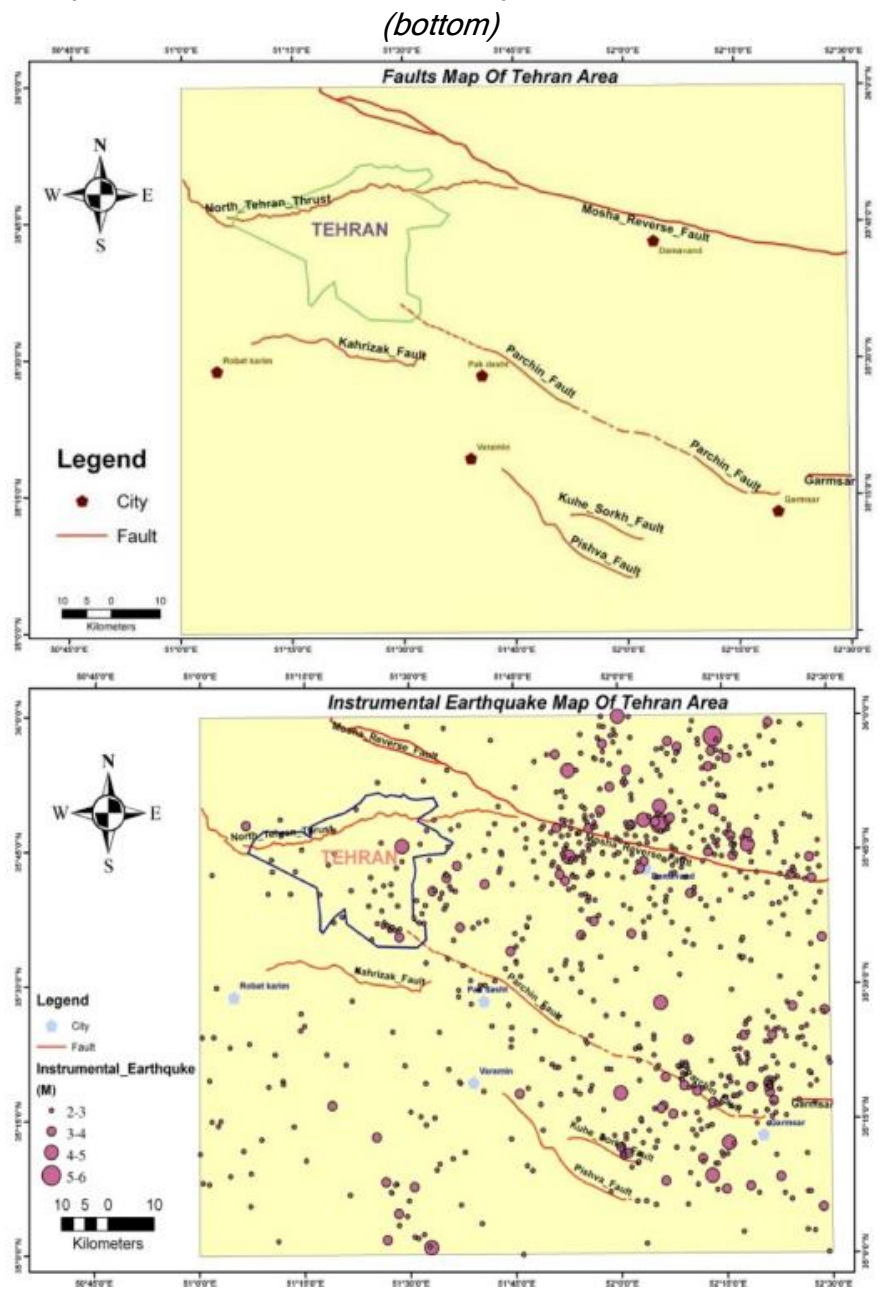

M.Arian et al.

Indian J.Sci.Technol.
Research article

CIndian Society for Education and Environment (iSee)
"Geomorphic study of Tehran area" http://www.indjst.org 
Tehran city and around cities. Then after structural, seismic and active tectonic studies seven main faults with high seismogenic have been introduced (Fig.1).

1-Mosha fault, is extended from north east of Amin Abad village to 45 $\mathrm{km}$ east of Qazvin which is about 200 $\mathrm{km}$ and strike N110-153 and dip to north direction (Fig.1). This fault is a reverse fault with a left lateral strike slip component in younger movements.

Table 1. Calculated results of movement potential of studied faults.

\begin{tabular}{|c|l|l|l|l|l|}
\hline NO & \multicolumn{1}{|c|}{ Fault Name } & Fault Position & $\begin{array}{c}\text { Fault polar } \\
\text { Position }\end{array}$ & $\theta$ Angle & \multicolumn{1}{|c|}{ FMP } \\
\hline 1 & Fault Mosha & $143-153,35-70$ & $143-153,56-22$ & $36-51$ & $0.2-0.7$ \\
\hline 2 & North Tehran fault & $57-89,10-80$ & $148-182,12-82$ & $57-72$ & $0.9-0.4$ \\
\hline 3 & Kahrizak fault & $70,70-80$ & $12-22,162$ & $43-44$ & 0.4 \\
\hline 4 & Parchin fault & $307,49-55$ & $35-41,217$ & $28-33$ & 0.1 \\
\hline 5 & Pishva fault & $324,50-58$ & $32-40,237$ & $36-40$ & $0.2-0.3$ \\
\hline 6 & Kuh-e Sorkh fault & $306,30-40$ & $50-60,216$ & $40-51$ & $0.3-0.7$ \\
\hline 7 & Garmsar fault & $266,40-45$ & $45-50,176$ & $43-48$ & $0.4-0.6$ \\
\hline
\end{tabular}

Accompanied with distinguishing high potential of

2- North Tehran fault, is extended from east of Lashgarak valley in north east of Tehran to Kazem Abad village and continue to Karaj city. The length of this fault is more than $75 \mathrm{~km}$ with strike N115E and dip 30-80 to north direction. This is a thrust fault with a left lateral strike slip component.

3- Kahrizak fault, with more than $90 \mathrm{~km}$ has been located in $10 \mathrm{~km}$ south of Rey city. Strike of this fault is N70- $80 \mathrm{~W}$ with dip 70-80 to north direction. It is a thrust fault with a right lateral strike slip component (Demartini et al., 1998).

4- Parchin Fault, with length of $70 \mathrm{~km}$, begins from North West and continues to North West of Garmsar. The strike of this fault is N307 with dip 19-53 to north east direction. It is a reverse fault (Berberian, 1981).

5- Pishva fault, with length of $37 \mathrm{~km}$ has been extended from south east Varamin to south east Kuh-e Gach Anticline. The strike is N324 and dip is 50-58 to north east direction). It is a reverse fault.

6- Kuh-e Sorkh fault, with length of $22 \mathrm{~km}$ begins from North West Kuh-e Sorkh anticline and continues to Takhte Rostam Mountains. The strike is N306 with dip 30-40 to north direction. It is a thrust fault with a left lateral component.

7- Garmsar fault, with length about $56 \mathrm{~km}$ long begins from south west Lasegerd. East path of this fault doesn't continue to salt diaper of Garmsar and also west part doesn't continue to Parchin fault. The strike of this fault is N226 with dip 40-45 to north direction. It is a thrust fault (Berberian, 1981).

\section{Fault movement potential}

In this part, movement potential of main seismogenic of faults has been calculated. According to main directions of studied faults in the area, two main directions of NW- SE and E-W in the area have been recognized. Parchin, Pishva, Kuh-e Sorkh and Mosha faults have 300-324 direction with medium and high dip. E - W group of faults is consisting of Kahrizak fault and two main thrust (Garmsar \& North Tehran faults). At first, on the basis of fault plane position and direction of area tectonic stress, the range of $\theta$ angle for each fault has been calculated then by using of movement potential equivalence (Lee et al., 1997), movement potential (FMP) for each fault has been calculated (Table 1).

seismicity on the basis of ancient, historical and instrumental earthquakes and introducing the main seismic sources (7 main \& seismogenic faults) and high seismic background of Mosha fault and limited region between two Parchin and Garmsar faults and low seismic background of Rey faults region particularly earthquakes with magnitude $>3$ degree in Richter scale, movement potential of faults have been calculated (Table 1), resulted in North Tehran fault has the highest potential $(90 \%)$ and Parchin fault has the least movement potential $(10 \%)$.

\section{Geomorphic Indexes}

Transverse topographic symmetry factor

The Transverse Topographic Symmetry Factor $(T)$ is a method that evaluates the amount of asymmetry of a river within a basin and the variation of this asymmetry in different segments of valley. The basin midline would be the location of a river that is symmetrically placed with regard to the basin divide. It is calculated regarding the larger axis of the basin, which extends from the outlet of the basin to the most distal point in the headwater. For each segment, $T$ is the ratio of the distance from the basin midline to the active meander-belt midline $(\mathrm{Da})$ and to the basin divide (Dd):

$\mathrm{T}=\mathrm{Da} / \mathrm{Dd}$

This value varies between 0 and 1 , which represent the minimum and maximum asymmetry of a segment respectively. It can be represented as a two-dimensional vector with a length equivalent to $\mathrm{Da} / \mathrm{Dd}$, and a direction perpendicular to the segment that indicates movement of the segment (as well as the river) with regard to the basin midline (Salvany, 2004).

\section{Asymmetric factor}

The Asymmetric Factor (AF) is a way to evaluate the existence of tectonic tilting at the scale of drainage basin. It is defined as $A F=100$ (Ar / At)

Where $A r$ is the area of the basin to the right of the trunk stream and At is the total area of the drainage basin. When $A F=50$, the drainage basin is perfectly symmetric, while values greater or less than 50 belong to asymmetric basins. This method may be applied over a relatively large area (Keller \& Pinter, 2002).

\section{Drainage basin shape}

Relatively young drainage basins in active tectonic areas tend to be elongated in shape normal to the 
topographic slope of mountain. With continued evolution or less active tectonic processes, the elongated shape tends to evolve to a more circular shape (Bull \& McFadden, 1977). Horizontal projection of basin shape may be described by the elongation ratio, Bs (RamírezHerrera, 1998) expressed by equation

$\mathrm{Bs}=\mathrm{Bl} / \mathrm{Bw}$

where $\mathrm{Bl}$ is the length of the basin, measured from its outlet to the most distal point in the drainage divide, and $\mathrm{Bw}$ is the width of the basin measured across the short axis. The index reflects differences between elongated basins with high values of Bs, and more circular basins with low values.

Basins with elongated shapes are characteristic of tectonically active areas, where the stream was primarily down cutting. Rapidly uplifted mountain fronts generally produce elongated, steep basins; and when tectonic activity is diminished or ceases, widening of the basins occur from the mountain front up (Ramírez-Herrera, 1998).

Ratio of valley floor width to valley height

$\mathrm{Vf}$ is defined as the ratio of the width of the valley floor to its average height (Bull \& McFadden, 1977) and is computed by:

$V f=2 V f w /[(E l d-E s c)]+(E r d-E s c)]$

where $\mathrm{Vf}$ is the ratio of valley floor width to valley height; $\mathrm{Vfw}$ is the width of the valley floor; Eld is the elevation of the divide on the left side of the valley; Erd is the elevation on the right side; and Esc is the average elevation of the valley floor. This index differentiates between valleys with a wide floor relative to the height of valley walls with a "U" shape compared to narrow, steep valleys with a "V" shape.

Valleys with a $U$ shape generally have high values of $\mathrm{Vf}$, whereas $\mathrm{V}$-shaped valleys with relatively low values. Because uplift is associated with incision, the index is thought to be a surrogate for active tectonics where low values of $\mathrm{Vf}$ are associated with higher rates of uplift and incision.

The index is a measure of incision and not uplift; but in an equilibrium state, incision and uplift are nearly matched. Calculation of the index is done at a prescribed distance upstream from the mountain front (Silva et al., 2003).

\section{Discussion}

The base of the most recent structures of the Alborz mountain range was a Pleistocene uplifting phase that formed some large thrust faults such as Mosha, Taleghan, Emamzadeh Davud and Purkan-Vadij faults (Dedual, 1967). The Mosha fault with at least $4 \mathrm{~km}$ displacement (Allenbach, 1966) is the youngest feature in the area that across other structures.

A tight compression in the Central Alborz with fold axis trending NW-SE also produced during the Late Pliocene phase (Gansser \& Huber, 1962). The main folds in the study area are the Kahar anticline, Kuh-e Morud,
Vol. 5 No. 3 (Mar 2012)

ISSN: 0974- 6846

Fig.2. Basin asymmetry vectors for the Karaj River and tributaries in the Karaj drainage basin. Length of the vectors denotes magnitude, adapted from Khavari et al. (2009).

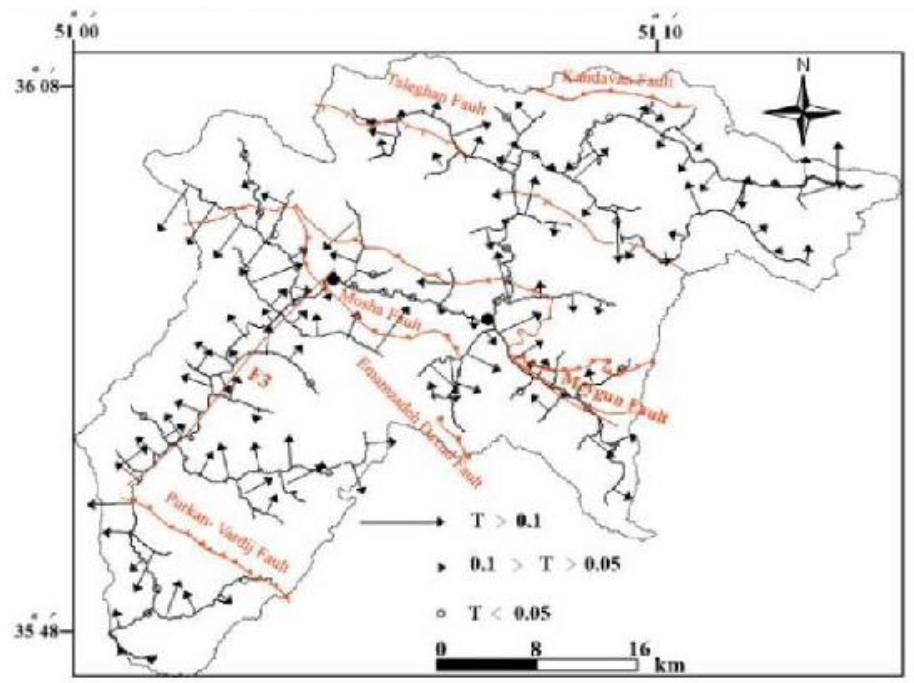

Varishsangan Anticline and the Arangeh Syncline (Gansser \& Huber, 1962).

The morphometric analysis described above allows us to interpret the tilting of the Karaj River and its tributaries based on their positions and flow direction respect to the tectonic structures of the study area. Based on tilting pattern, three different areas were distinguished: (1) A northern area, equivalent to the region with Paleozoic--Mesozoic bedrock, extends from Gachsar to Doab valley with $T$ values ranged from 0.02 to 0.25 ( $T$ average $=0.08$ ) and migration direction of the Karaj river toward W-NW.

(2) A central area from Doab to Asara with Tertiary bedrock and a little tilting ( $T$ average $=0.04$ ).

(3) A southern area from Asara to Bailaghan with Tvectors generally shows a main $\mathrm{W}-\mathrm{NW}$ direction. T values in this part ranged from 0.01 to 0.61 and the mean was 0.3 .

The major tributaries tilted to different directions depend on their flow directions respect to the structures; the rivers parallel to the structures have NE T-vectors, while the rivers perpendicular to the structures display WNW T-vectors (Fig 2).

\section{Relative tectonic activity}

Some of the geomorphic indexes can be the primary method for identifying of area with rapid tectonic deformations. This method can rapidly consider for vast area (Keller \& Pinter, 2002). All data for this kind of measurements have been extracted from topography maps of Tehran area in scale of 1:50000 and 1:250000. In the following you can find the most applied geomorphic indexes for active tectonic studies. So, these indexes have been calculated.

Meanwhile calculating $\mathrm{Vf}$ index (the relation between width bottom of valley and high) has been observed that $\mathrm{Vf}$ index of Mosha fault has been decreased from 
Table 2. Classification of relative tectonic activity of studied area.

\begin{tabular}{|c|l|c|l|c|c|c|c|c|}
\hline No & Front Name & Front Type & $\begin{array}{c}\text { Orientation } \\
\text { of front }\end{array}$ & $\begin{array}{c}\text { Front } \\
\text { Length(km) }\end{array}$ & Max Relief & SMF & VF Ave. & $\begin{array}{c}\text { Relative Tectonic } \\
\text { Activity Classification }\end{array}$ \\
\hline 1 & Mosha & Fault & NW-SW & 118.58 & 2500 & 1.02 & 0.65 & 1 \\
\hline 2 & $\begin{array}{l}\text { North } \\
\text { Tehran }\end{array}$ & Fault & NE-SW & 65 & 2000 & 1.06 & 1.36 & 2 \\
\hline 3 & Garmsar & Fault & W-E & 62.44 & 1565 & 1.13 & 1.29 & 1 \\
\hline 4 & Kuh-e Sorkh & Fault & W-E & 22.19 & 1365 & 1.04 & 0.55 & 1 \\
\hline 5 & Pishva & Fault & NE-SE & 32.61 & 1142 & 1.12 & 1.26 & 1 \\
\hline 6 & Parchin & Fault & NW-SE & 83.41 & 1499 & 1.22 & 1.1 & $1-2$ \\
\hline 7 & Kahrizak & Fault & NW-SE & 38.51 & 1380 & 1.4 & $?$ & $?$ \\
\hline
\end{tabular}

Hezardasht to Meygoun. Also this index for North Tehran fault has been increased from Gandom - Mageh to Hesarak. It shows that relative active of Mosha fault from Hezardasht to Meygoun has been increased, but North Tehran fault active from Gandom- Mageh to Hesarak has been decreased.

Classification of Frontal mountain based on relative tectonic activities is a new relative method and we must know results of this method in only relative distinction in one area. This area which has been located in border of south Alborz with central Iran, basically has high tectonic activities (Table 2). The studied area has two levels of relative Tectonic activities.

$\mathrm{Vf}$ index of Kahrizak fault could not be evaluate even on topographic map in scale of 1:250000, therefore we have marked it with question mark. Anyhow in this research in comparison of others, Mosha and Kuh-e Sorkh faults according to have the most level of relative tectonic activity and Pishva fault has the least level.

\section{Conclusions}

It have been distinguished that studied area include seven main seismogenic faults and North Tehran fault has the highest of movement potential $(90 \%)$ and Pishva fault has the lowest movement potential $(10 \%)$ in current tectonic regime.

Also, Northern part of Tehran area has been tilted. Tilting direction has changed along the Karaj River by differentiation of neo-tectonics activity of the south Central Alborz. The data are consistent with a NW tilting where the orientations of folds and fault blocks are perpendicular to the rivers, but where the structures oriented in the parallel directions to the rivers, tilting orientation is NE.

\section{Acknowledgements}

This work is funded by the Department of Geology, Islamic Azad University, Science and Research Branch, Tehran, Iran. Also, Special thanks to Vice-President for Research in Science and Research Branch, Tehran.

\section{References}

1. Allenbach P (1966) Geologie und Petrographie des Damavand und seiner Umgebung (Zentral Elburz), Iran: Mitteilungen aus dem Geologischen Institute der
Eidgenoessischen Technischen Hochschule und der Universitaet Zurich. Neue Folge. 63, 144.

2. Ambraseys NN and Melville CP (1982) A history of Persian earthquakes. Cambridge Univ. Press, London, pp: 219.

3. Berberian M (1981) Active tectonic faulting and tectonics of Iran. Am. Geophys. UN \& Geol. Soc. Am., Geodynamics Series. 3, 33-69.

4. Berberian $M$, Ghorashi $M$, Arzhangravesh $B$ and Mohajer-Ashjai A (1983) Active fault map of the Tehran quadrangle (1:250000). Geo. Surv. Iran. Rep.1, 56.

5. Berberian $M$, Ghoreshi $M$, Arjang Ravesh $B$ and Mohajer Ashjai A (1992) Seismotectonic and earthquake -fault hazard investigation in the Tehran region. Geol. Sur. Iran. 2, 315.

6. Bull WB and McFadden LD (1977) Tectonic geomorphology north and south of the Garlock fault, California. In: Doehring, D.O (eds), Geomorphology in Arid Regions. Proc. $8^{\text {th }}$ Annual Geomorphol. Sym., State Univ. NY, Binghamton, pp. 115-138.

7. Dedual E (1967) Zur geologie des mittleren und unteren Karaj-Tales, Zentral-Elburz (Iran): Mitteilungen aus dem Geologischen Institute der Eidgenoessischen Technischen Hochschule und der Universitaet Zurich, Zürich, SUISSE (Université de soutenance), Neue Folge 76, pp: 123. INIST-CNRS, Cote INIST: TM 936.

8. Demartini PM, Hessami K, Pantosti D, Addezio GD, Alinaghi M and Ghafory Ashtiani M (1998) A geologic contribution to the evaluation of the seismic potential of the Kahrizak fault (Tehran, Iran). Tectonophysics. pp: 187-199.

9. Gansser A and Huber H (1962) Geological observations in the central Alborz, Iran. Schweizerische Mineralogische \& Petrographische Mitteilungen. 42, 583-630.

10. Keller EA and Pinter N (2002) Active tectonics, Earthquakes, Uplift and Landscape (2nd edition). Prentice Hall Earth Sci. Series. pp: 362.

11. Khavari R, Arian M and Ghorashi M (2009) Neotectonics of the south central Alborz drainage basin, In NW Tehran, N Iran. J. Appl. Sci. 9(23), 4115-4126. 
12. Lee CF, Hou JJ and Ye H (1997) The movement potential of the major faults in Hong Kong area. Episodes. 20(4), 227-23.

13. Nazari $H$ (2005) Seismotectonic map of the central Alborz $(1: 250,000)$. Seismotectonic Dept. Geol. Sur. Iran.

14. Ramírez-Herrera MA (1998) Geomorphic assessment of active tectonics in the Acambay Graben, Mexican volcanic belt. Earth Surface Processes \& Landforms. 23, 317-332.

15. Ritz JF, Nazari H, Ghassemi A, Salamati R, Shafei A, Solaymani $S$ and Vernant P (2006) Active transtension inside Central Alborz: A new insight into northern Iran-southern Caspian geodynamics. Geological Soc. America. 34, 477-480.

16. Salvany JM (2004) Tilting neo-tectonics of the Guadiamar drainage basin, SW Spain. Earth Surface Processes \& Landforms. 29, 145-160.

17. Silva PG, Goy JL, Zazo C and Bardajm T (2003) Fault generated mountain fronts in Southeast Spain: geomorphologic assessment of tectonic and earthquake activity. Geomorphol. 50, 203-225.

18. Solaymani SH, Feghhi Kh, Shabanian E, Abbassi MR and Ritz JF (2002) Preliminary paleoseismological study along the Mosha fault at Mosha valley. International institute of earthquake engineering and seismology. Ministry Sci. Res. \& Technol. Tehran, Iran, No: 81-2003-3. pp: 96.

19. Tchalenko JS, Ambraseys $\mathrm{NN}$ and Berberian $\mathrm{M}$ (1974a) Materials for the study of seismotectonics of Iran. North-Central Iran. Geol. Sur. Iran. 2, 29.

20. Tchalenko JS, Berberian M, Iranmanesh I, Bailly M and Arsovsky M (1974b) Tectonic framework of the Tehran Region; in materials for the study of seismotectonics of Iran. North Central Iran. Geol. Surv. Iran. 29, 7-46.

21. Vernant $P H$, Nilforoushan $F$, Chery $J$, Bayer $R$, Djamour Y, Masson F, Nankali H, Ritz JF, Sedighi M and Tavakoli F (2004) Deciphering oblique Shorting of central Alborz in Iran using geodetic data. Earth \& Planetary Sci. Lett. 223, 1-2, pp: 177-185. 